\title{
Lithium Chemistry of Lithium Doped Magnesium Oxide Catalysts Used in the Oxidative Coupling of Methane $^{a}$
}

\author{
S.J. KORF*, J.A. ROOS, N.A. DE BRUIJN, J.G. VAN OMMEN and J.R.H. ROSS \\ Faculty of Chemical Technology, University of Twente, PO BOX 217, 7500 AE Enschede \\ (The Netherlands)
}

(Received 24 July 1989, revised manuscript 6 September 1989)

\begin{abstract}
Active sites are created on the surface of a $\mathrm{Li} / \mathrm{MgO}$ catalyst used for the selective oxidation of methane by the gradual loss of carbon dioxide from surface carbonate species in the presence of oxygen. Decomposition of the carbonate species in the absence of oxygen is detrimental to the activity of the catalyst. The active sites created are not stable but disappear either as a result of reaction with $\mathrm{SiO}_{2}$ to form $\mathrm{Li}_{2} \mathrm{SiO}_{3}$ or by the formation and subsequent loss of the volatile compound $\mathrm{LiOH}$. Ingeneral the addition of water to the gas feed is detrimental to the stability of the catalyst. In the case of $\mathrm{Li}_{2} \mathrm{CO}_{3}$ strongly bonded on the surface of $\mathrm{Li} / \mathrm{MgO}$ catalyst, the decomposition of the carbonate and thus the initial activity, can be enhanced by the addition of water to the gas feed. The addition of carbon dioxide to the gas feed results in a poisoning of the catalyst, the degree of this poisoning depending on the activity of the catalyst. The deactivation of the catalyst can be retarded if low concentration of carbon dioxide are added to the reaction mixture. It is possible to improve the stability of the catalyst by periodic reversal of the direction of flow of the gas steam.
\end{abstract}

\section{INTRODUCTION}

The partial oxidation of methane to form $\mathrm{C}_{2}$ and higher hydrocarbons is an alternative to the conversion of methane into synthesis gas (by steam reforming or partial oxidation) and subsequent reaction of the synthesis gas to produce refinery or petrochemical feedstocks [1-6].

The mechanism for this reaction is believed to involve initially the cleavage of a $\mathrm{C}-\mathrm{H}$ bond, this resulting in the formation of $\mathrm{CH}_{3}$ radicals which undergo coupling to form ethane.

We have previously presented results which suggested a possible model for the reactions which occur on the surface of a $\mathrm{Li} / \mathrm{MgO}$ catalyst [5]. Active sites

${ }^{a}$ This paper was presented at the Bicentenary Catalysis Conference in Sydney, 1-2 September 1988 
are created on the surface in the presence of oxygen by the gradual loss of carbon dioxide from surface lithium carbonate species. The sites created are not stable but are destroyed as a result of the formation of the volatile $\mathrm{LiOH}$ or by reaction with $\mathrm{SiO}_{2}$. The presence of carbon dioxide in the gas feed has two effects: to poison reversibly the active sites for the oxidative coupling reaction, but also to stabilise them against deactivation. In order to obtain further evidence for this model, we have carried out a number of different additional types of measurements. Several samples of $\mathrm{Li} / \mathrm{MgO}$ catalysts, prepared by different methods of preparation or with different lithium and carbon dioxide contents, have been studied in ageing experiments. As in the use of $\mathrm{Li}$ / $\mathrm{MgO}$ catalysts for methane coupling, the manner of decomposition of the $\mathrm{Li}_{2} \mathrm{CO}_{3}$ species on the $\mathrm{MgO}$ support has been found to be very important, the decomposition of the surface carbonate species has now been studied with temperature-programmed decomposition (TPD) to attempt to show a relationship between the TPD results and the catalytic behaviour. The catalysts were pretreated in $\mathrm{He}, \mathrm{CH}_{4}, \mathrm{H}_{2}, \mathrm{O}_{2}$ or $\mathrm{CO}_{2}$ and it was found that these pretreatments have a decisive influence on the formation of the $\mathrm{C}_{2}$ products. Results showing the effect of the addition of carbon dioxide and water to the gas feed have also been obtained for several of the catalyst samples. Finally, it has been shown that periodic reversal of the direction of flow of the gas stream has a beneficial effect on the stability of the catalyst. It will be shown that each of these separate sets of results gives additional support for the model outlined above [5].

\section{EXPERIMENTAL}

\section{Catalyst preparation}

Table 1 shows details of the $\mathrm{Li} / \mathrm{MgO}$ catalyst used in this study. These were all prepared by wet impregnation of $\mathrm{MgO}$ (Merck p.a.) with an aqueous solution of $\mathrm{LiOH} \cdot \mathrm{H}_{2} \mathrm{O}$; for some of the samples, this was done in the presence of a stream of carbon dioxide (see below). After drying at $140^{\circ} \mathrm{C}$, all the samples, with one exception, were calcined in air at various temperatures $\left(T_{\mathrm{c}}\right)$; sample $\mathrm{A}_{2}$ was calcined in carbon dioxide at $850^{\circ} \mathrm{C}$. The calcined catalysts were crushed and sieved to a grain size of $0.3-0.6 \mathrm{~mm}$ before use.

$\mathrm{Li} / \mathrm{MgO} \mathrm{A} 1$ and $\mathrm{Li} / \mathrm{MgO} \mathrm{A} 2$ were prepared by wet impregnation in the presence of a stream of carbon dioxide which was passed through the evaporating solution for $8 \mathrm{~h}$. The difference between these two catalysts is the calcination atmosphere. $\mathrm{Li} / \mathrm{MgO} \mathrm{A} 1$ was calcined in air at $850^{\circ} \mathrm{C}(6 \mathrm{~h})$ and $\mathrm{Li} / \mathrm{MgO} \mathrm{A} 2$ was calcined in carbon dioxide at $850^{\circ} \mathrm{C}(6 \mathrm{~h})$; the latter treatment resulted in a higher lithium content as shown in Table 1 . In the case of the $\mathrm{Li} / \mathrm{MgO} \mathrm{B}$ catalysts, carbon dioxide was present during the impregnation step for a total of $4 \mathrm{~h}$. The resultant materials were calcined in air for $6 \mathrm{~h}$ at different temperatures [5]. $\mathrm{Li} / \mathrm{MgO} \mathrm{C}$ was prepared in the same way as $\mathrm{Li} / \mathrm{MgO} \mathrm{B}$ and was 


\section{TABLE 1}

Details of preparation, analysis, percent lithium present as carbonate (anything above $100 \%$ must be present as $\mathrm{MgCO}_{3}$ ), area and carbonate decomposition temperature for the different samples used in this work

\begin{tabular}{llllllll}
\hline $\mathrm{Li} / \mathrm{MgO}$ & $\begin{array}{l}\mathrm{CO}_{2} \text { present during } \\
\text { impregnation } \\
(\mathrm{h})\end{array}$ & $\begin{array}{l}T_{\mathrm{c}}(6 \mathrm{~h}) \\
\left({ }^{\circ} \mathrm{C}\right)\end{array}$ & $\begin{array}{l}\mathrm{Li} \\
(\mathrm{wt} . \%)\end{array}$ & $\begin{array}{l}\mathrm{CO}_{2} \\
(\mathrm{wt} . \%)\end{array}$ & $\begin{array}{l}\chi \\
(\%)\end{array}$ & $\begin{array}{l}\text { Area } \\
\left(\mathrm{m}^{2} / \mathrm{g}\right)\end{array}$ & $\begin{array}{l}T_{\mathrm{d}} \\
\left({ }^{\circ} \mathrm{C}\right)\end{array}$ \\
\hline $\mathrm{A} 1$ & 8 & 850 air & 2.18 & 7.91 & 114 & & 662 \\
$\mathrm{~A} 2$ & 8 & $850 \mathrm{CO}_{2}$ & 3.52 & 15.07 & 135 & & 700 \\
$\mathrm{~B}$ & 4 & 500 & 3.40 & 11.64 & 108 & 43.8 & \\
& & 600 & 3.50 & 11.77 & 106 & 9.9 & \\
& & 700 & 3.40 & 10.08 & 94 & 2.5 & \\
& & 800 & 3.30 & 9.18 & 88 & 0.4 & \\
& & 850 & 3.10 & 8.24 & 84 & 0.4 & 675 \\
$\mathrm{C}$ & 4 & 850 & 5.40 & 12.50 & 73 & & 725 \\
$\mathrm{D}$ & & & & & & & \\
$\mathrm{D} 1$ & & & & & & & \\
$\mathrm{D} 2$ & & 850 & 1.70 & 4.35 & 80 & 0.3 & 662 \\
& & 850 & 3.20 & 7.39 & 73 & 0.1 & 685 \\
\hline
\end{tabular}

$\chi$ gives the percentage of lithium present as carbonate.

$T_{\mathrm{d}}$ is the temperature at which the decomposition of the $\mathrm{Li}_{2} \mathrm{CO}_{3}$ on $\mathrm{MgO}$ starts.

It was shown with XRD that all the samples calcined at $850^{\circ} \mathrm{C}$ consisted of $\mathrm{Li}_{2} \mathrm{CO}_{3}$ and $\mathrm{MgO}$.

calcined in air at $850^{\circ} \mathrm{C}(6 \mathrm{~h})$ but contained more lithium than the other materials. The $\mathrm{Li} / \mathrm{MgO} \mathrm{D}$ samples were prepared without passing carbon dioxide through the evaporating solution during impregnation. The two materials of this series had different lithium contents and were calcined in air at $850^{\circ} \mathrm{C}$ for $6 \mathrm{~h}$.

\section{Catalyst analysis and characterisation}

The analysis of the samples is also given in Table 1. Atomic absorption spectroscopy (AAS) was used to determine the weight percentages of lithium. The carbonate contents were determined by wet analysis using the Blom-Edelhausen method. X-ray powder diffraction was carried out with a Philips PW 1710 diffractometer, using $\mathrm{Cu} \mathrm{K} \alpha$ radiation. Surface areas were determined by the BET method, using argon adsorption. Thermogravimetric studies of the catalysts to determine the decomposition of the carbonate were carried out with a Du Pont system (990 control unit, 951 TG unit); the heating rate used was $20^{\circ} \mathrm{C} \mathrm{min}^{-1}$ in nitrogen $\left(0.42 \mathrm{~cm}^{3}(\mathrm{STP}) \mathrm{s}^{-1}\right)$. The decomposition of lithium carbonate species on the $\mathrm{MgO}$ support was also studied with temperature pro- 
grammed decomposition (TPD); this comprised a flow system equipped with a thermal conductivity cell in which the sample was heated at a constant rate $\left(14^{\circ} \mathrm{C} \mathrm{min}^{-1}\right)$ in a stream of helium. XPS data were obtained from a VG ESCALAB.

\section{Catalytic experiments}

The catalytic experiments were carried out with a reaction system containing a quartz fixed-bed reactor of $5 \mathrm{~mm}$ internal diameter operated at a total pressure of $1 \mathrm{~atm}$. The gas feed to the reactor consisted of methane $(0.67 \mathrm{bar})$, oxygen $(0.07 \mathrm{bar})$ and helium $(0.26 \mathrm{bar})$. All of the gases were analysed by gas chromatography [6]. Two sets of reaction conditions were used, each with the same contact time in the catalyst bed: (i) low superficial gas velocity, with a catalyst weight, $W$, of $0.093 \mathrm{~g}$ and a gas flow, $F$, of $0.42 \mathrm{~cm}^{3}$ (STP) s${ }^{-1}$; and (ii) high specific gas velocity, with $W=0.750 \mathrm{~g}$ and $F=3.33 \mathrm{~cm}^{3}$ (STP) s ${ }^{-1}$. Unless otherwise stated, the high superficial gas velocity conditions were used.

In one experiment, te reaction system was equipped with a membrane pump which brought about external recirculation of the product gas [7]. The recycle flow amounted to $4.0 \mathrm{~cm}^{3}$ (STP) $\mathrm{s}^{-1}$ and a net flow of $0.13 \mathrm{~cm}^{3}$ (STP) $\mathrm{s}^{-1}$ through the system was used. With this ratio (30) of recycle flow to net flow, the reactor may be considered to be gradientless with regard to the concentrations of reactants and products [8]. In this system, $0.5 \mathrm{~g}$ of catalyst was used. The reactor feed consisted of methane ( 0.50 bar $)$, oxygen ( 0.10 bar $)$ and helium $(0.40 \mathrm{bar})$. In order to prevent condensation in the lines, water was removed continuously in the recycle-loop.

\section{RESULTS AND DISCUSSION}

\section{Catalyst pretreatment}

\section{Effect of calcination atmosphere}

Fig. 1 shows the yield of $\mathrm{C}_{2}$ products as a function of the reaction temperature, $T_{\mathrm{R}}$, in experiments using a low superficial gas velocity, for a sample of the $\mathrm{Li} / \mathrm{MgO} \mathrm{B}$ series [5] calcined in air at $500^{\circ} \mathrm{C}$ and then pretreated in the reactor at $800^{\circ} \mathrm{C}$ for $3 \mathrm{~h}$ in a series of different gases: $\mathrm{He}, \mathrm{CH}_{4}, 5 \% \mathrm{H}_{2} / \mathrm{Ar}$, air or $\mathrm{CO}_{2}$. It can be seen that the yield of $\mathrm{C}_{2}$ products can be greatly influenced by the manner of pretreatment. At low $T_{R}$, the highest $C_{2}$ yield was reached with the sample calcined in air at $500^{\circ} \mathrm{C}$. At high $T_{R}$, however, the highest $\mathrm{C}_{2}$ yield was reached with the carbon dioxide pretreated sample. Pretreatment in $\mathrm{He}, 5 \% \mathrm{H}_{2} / \mathrm{Ar}$ and $\mathrm{CH}_{4}$ resulted in low $\mathrm{C}_{2}$ production. Fig. 2 shows the $\mathrm{C}_{2}$ selectivity as a function of $T_{\mathrm{R}}$ : pretreatment in $5 \% \mathrm{H}_{2} / \mathrm{Ar}$ and $\mathrm{CH}_{4}$ resulted in the lowest $\mathrm{C}_{2}$ selectivities, showing that not only the number of the active sites 


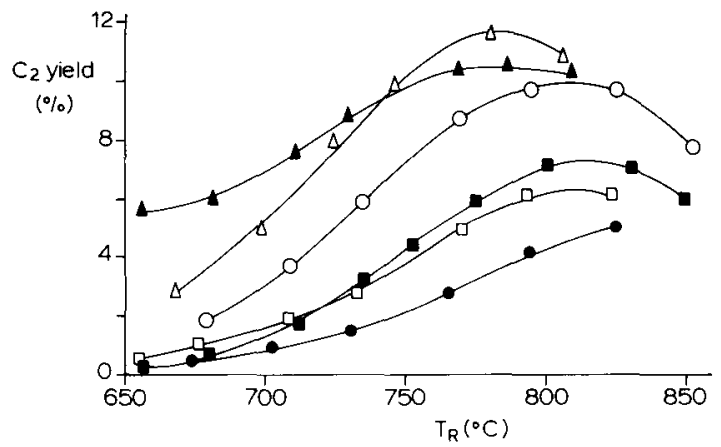

Fig. 1. The $\mathrm{C}_{2}$ yield as a function of $T_{\mathrm{R}}$ for a sample of $\mathrm{Li} / \mathrm{MgO} \mathrm{B}(\Delta)$ calcined at $500^{\circ} \mathrm{C}$ and preheated in the reactor in $\mathrm{He}(\square), \mathrm{CH}_{4}(\boldsymbol{\square}), 5 \% \mathrm{H}_{2} / \mathrm{Ar}(\bullet)$, air $(\mathrm{O})$ or $\mathrm{CO}_{2}(\triangle)$ for $3 \mathrm{~h}$ at $800^{\circ} \mathrm{C}$.

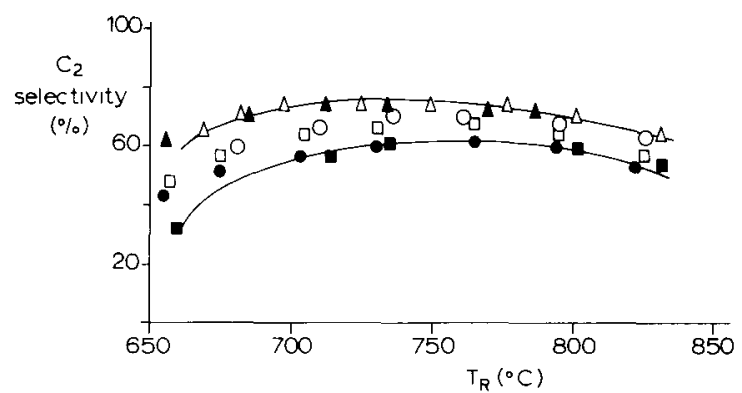

Fig. 2. The $\mathrm{C}_{2}$ selectivities as a function of $\mathrm{T}_{\mathrm{R}}$ for the data of Fig. 1. Symbols as in Fig. 1.

decreased but also that the nature of the active sites was probably altered. It should be noted that if the pretreatments in $\mathrm{He}, 5 \% \mathrm{H}_{2} / \mathrm{Ar}$ and $\mathrm{CH}_{4}$ were carried out in another system and the resultant materials were exposed to the atmosphere before testing, the results were equivalent to those of the sample precalcined in air: upon exposure to the atmosphere, the catalyst appears to react with carbon dioxide to form lithium carbonate, thus regenerating itself [5]. As was shown by elemental analysis there was almost no loss of lithium during the different pretreatments of the catalyst at $800^{\circ} \mathrm{C}$. We hence conclude that the high temperature treatment "in situ" in atmospheres which do not contain air or carbon dioxide is detrimental to the catalyst. These results show that the decomposition of the lithium carbonate species on the $\mathrm{MgO}$ support in the absence of oxygen $\left(\mathrm{He}, 5 \% \mathrm{H}_{2} / \mathrm{Ar}, \mathrm{CH}_{4}\right)$ is detrimental to the subsequent activity of the catalyst, as it cannot be regenerated under reactions conditions.

\section{Effect of calcination temperature}

It was shown using TGA and TPD that the $\mathrm{Li} / \mathrm{MgO} \mathrm{B}$ catalysis calcined at low values of $T_{\mathrm{c}}$ showed a loss carbon dioxide at relatively low temperatures $\left(<650^{\circ} \mathrm{C}\right)$, suggesting that some $\mathrm{MgCO}_{3}$ is present. At higher temperatures $\left(>650^{\circ} \mathrm{C}\right.$ ), all the catalysts lost carbon dioxide (Figs. 3a and b). 

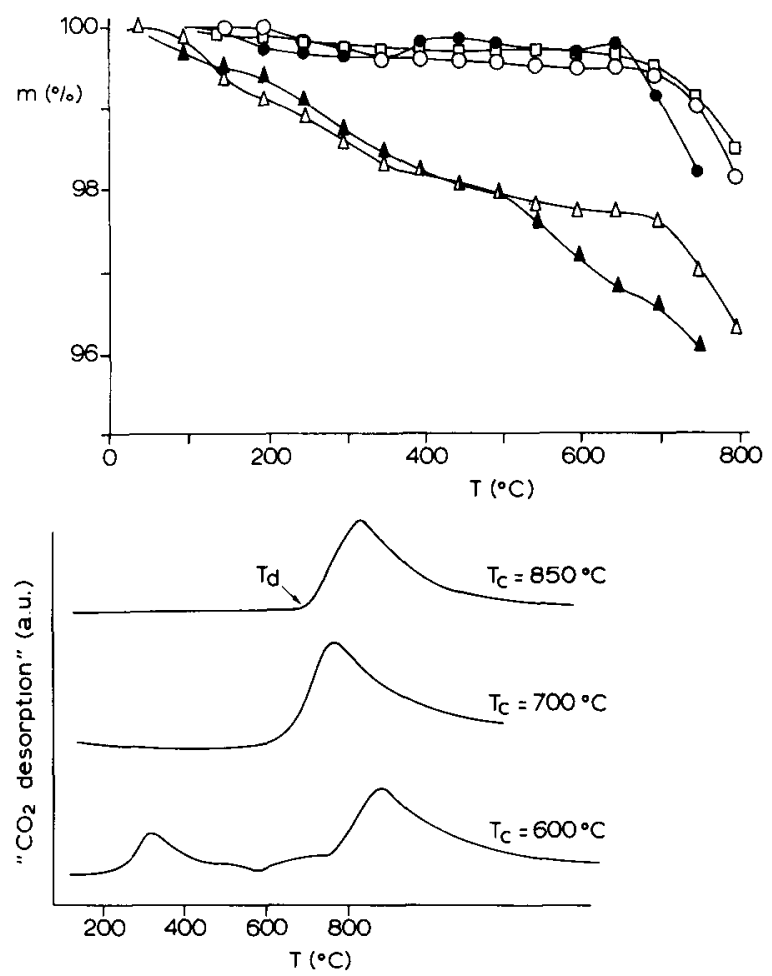

Fig. 3. (a) Thermogravimetric curves for the $\mathrm{Li} / \mathrm{MgO}$ B series, ( $\Delta) 500^{\circ} \mathrm{C},(\Delta) 600^{\circ} \mathrm{C},(\square)$ $700^{\circ} \mathrm{C},(\mathrm{O}) 800^{\circ} \mathrm{C},(\bullet) 850^{\circ} \mathrm{C}$. (b) TPD data for the $\mathrm{Li} / \mathrm{MgO}$ B series.

The surface areas of the samples of Series $B$ calcined at various temperatures are also given in Table 1; it can be seen that there is a substantial loss in area with increase in calcination temperature.

In a previous paper [5] we have shown that low $T_{\mathrm{c}}$ values resulted in relatively high $\mathrm{C}_{2}$ yields at low $T_{\mathrm{R}}$ compared with the results for high $T_{\mathrm{c}}$. The results at higher $T_{R}$ (above about $780^{\circ} \mathrm{C}$ ) were approximately the same for all values of $T_{\mathrm{c}}$. After reaction had taken place at high temperatures and the temperature was lowered once more, the relatively high $\mathrm{C}_{2}$ yields at low $T_{\mathrm{R}}$ were no longer obtained; results were now obtained similar to those for the material calcined at $850^{\circ} \mathrm{C}$, but the selectivities were effectively unchanged compared to the fresh material.

The weakly bonded carbonate species of the $\mathrm{Li} / \mathrm{MgO}$ catalysts calcined at low values of $T_{\mathrm{c}}$ are probably associated with a relatively high surface area. The relatively high activity, at low $T_{R}$, of the catalysts calcined at low values of $T_{\mathrm{c}}$ is associated with the decomposition of weakly bonded carbonate. The loss of yield observed after calcination at higher temperatures is probably largely due to the loss of catalyst area and the nature of the active site is essentially unchanged by this loss. 


\section{Influence of catalyst preparation on ageing behaviour}

To study the effect of catalyst preparation on the ageing behaviour, different types on $\mathrm{Li} / \mathrm{MgO}$ catalysts $\left(\mathrm{A} 1, \mathrm{~B}, \mathrm{C}, \mathrm{D} 1, \mathrm{D} 2 ; T_{\mathrm{c}}=850^{\circ} \mathrm{C}\right.$ ) were studied in ageing experiments at $T_{\mathrm{R}}=800^{\circ} \mathrm{C}$. The results are given in Fig. 4. The highest $\mathrm{C}_{2}$ yield was reached initially with $\mathrm{Li} / \mathrm{MgO} \mathrm{Al}$ for which impregnation was carried out in the presence of a stream of carbon dioxide passed through the evaporating solution for $8 \mathrm{~h}$. In the case of the sample $\mathrm{Li} / \mathrm{MgO} \mathrm{B}$, this step was carried out for $4 \mathrm{~h}$ and the result was a catalyst which was less active. Using the sample $\mathrm{Li} / \mathrm{MgO} \mathrm{D} 2$, which was prepared without passing carbon dioxide through the evaporating solution during impregnation, the initial $\mathrm{C}_{2}$ yield was only $8.2 \%$. However, the $\mathrm{C}_{2}$ yield with this sample increased with time: $\mathrm{a}_{2}$ yield of $12.2 \%$ was reached after $48 \mathrm{~h}$, a value which was similar to that for $\mathrm{Li}$ / $\mathrm{MgO} \mathrm{B}$ after $5 \mathrm{~h}$. The subsequent deactivation of the sample $\mathrm{Li} / \mathrm{MgO} \mathrm{D} 2$ was very rapid compared with $\mathrm{Li} / \mathrm{MgO}$ B even though $\mathrm{Li} / \mathrm{MgO} \mathrm{B}$ and $\mathrm{Li} / \mathrm{MgO}$ D2 contained almost the same amounts of lithium (Table 1). However, XPS measurements of the two samples showed that $\mathrm{Li} / \mathrm{MgO} \mathrm{B}$ contained more lithium on the surface than did $\mathrm{Li} / / \mathrm{MgO} \mathrm{D} 2$.

Table 1 also gives the amount of lithium which was present as carbonate in the various samples. In the case of $\mathrm{Li} / \mathrm{MgO} \mathrm{B}$ and $\mathrm{D} 1,84 \%$ and $73 \%$ respectively of the lithium was present as carbonate. Passing carbon dioxide through the evaporating solution during impregnation $(\mathrm{Li} / \mathrm{MgO} \mathrm{B})$ thus appears to have resulted in a higher amount of lithium present as carbonate and also in the segregation of lithium on the surface of the catalyst. The catalysts obtained by passing carbon dioxide through the evaporating solution during impregnation are very active.

$\mathrm{Li} / \mathrm{MgO} \mathrm{D} 1$, which contained only $1.70 \mathrm{wt} .-\% \mathrm{Li}$ in the fresh material, deac-

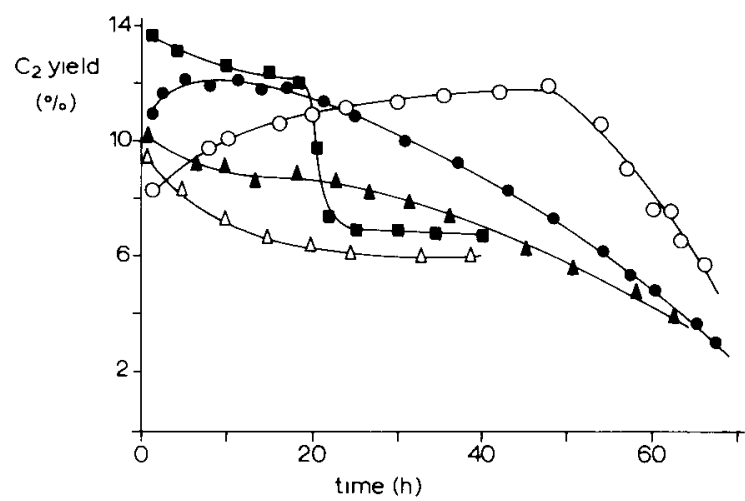

Fig. 4. The yield of $\mathrm{C}_{2}$ products as a function of time of reaction at $T_{\mathrm{R}}=800^{\circ} \mathrm{C}$ for samples prepared in different ways $\left(\mathrm{T}_{\mathrm{c}}=850^{\circ} \mathrm{C}\right.$ (see Table 1 for details of the samples). ( $(\boldsymbol{D}) \mathrm{A1},(\bullet) \mathrm{B},(\triangle) \mathrm{C}$, ( $\Delta$ ) D1, (O) D2. 
tivated relatively rapidly (Fig. 4). After preparation, a Li/MgO catalyst should thus contain a minimum of ca. $2.0 \mathrm{wt} .-\% \mathrm{Li}$ to prevent rapid deactivation $[2,5]$. The initial $\mathrm{C}_{2}$ yield of $\mathrm{Li} / \mathrm{MgO} \mathrm{C}$, which contained 5.40 wt.- $\% \mathrm{Li}$, was $10 \%$. This catalyst is thus relatively inactive. It was shown with TPD measurements that the decomposition of the lithium carbonate of this sample started at ca. $725^{\circ} \mathrm{C}\left(T_{\mathrm{d}}\right)$. The decomposition of the lithium carbonate of the other $\mathrm{Li} / \mathrm{MgO}$ materials, for which the catalytic data are also given in Fig. 4, started at lower temperatures (see Table 1); the other samples were initially more active (except $\mathrm{Li} / \mathrm{MgO}$ D2, see above). It thus appears that the high lithium content of the $\mathrm{Li} / \mathrm{MgO}$ sample $\mathrm{C}$ results in a high decomposition temperature for $\mathrm{Li}_{2} \mathrm{CO}_{3}$ on the surface of the $\mathrm{MgO}$ and that this leads to a relatively inactive catalyst.

As shown in Fig. 4, none of the $\mathrm{Li} / \mathrm{MgO}$ catalysts are stable. The deactivation of the catalysts appears to be caused partly by the loss of lithium by diffusion into the quartz of the reactor to form the $\mathrm{Li}_{2} \mathrm{SiO}_{3}$ phase and partly by the formation of the volatile $\mathrm{LiOH}$ [5]. Table 2 gives the lithium content of the different catalysts after the ageing experiment as well as the $\mathrm{C}_{2}$ selectivities after $5 \mathrm{~h}, 40 \mathrm{~h}$ and $65 \mathrm{~h}$. Using $\mathrm{Li} / \mathrm{MgO} \mathrm{B}$, the $\mathrm{C}_{2}$ yield decreased with time (Fig. 4); however, the $\mathrm{C}_{2}$ selectivity remained virtually constant throughout at a value of about $83 \%$ this indicating that the nature of the active site has not altered much but that the number of sites must have decreased during the experiment. However, some of the other $\mathrm{Li} / \mathrm{MgO}$ samples showed a decrease in $\mathrm{C}_{2}$ selectivity with time (Table 2). The drop in $\mathrm{C}_{2}$ selectivity appears to have been due to the deposition of silicon-containing species on the surface of the catalyst samples during use: XRF showed the presence of silicon in the used samples. When XRF analyses were carried out with powdered samples, a higher concentration of silica was found than when the analyses were carried out with fused samples; this appears to indicate that the silicon was probably concen-

\section{TABLE 2}

Data showing the deactivation of $\mathrm{Li} / \mathrm{MgO}$ catalysts $\left(T_{\mathrm{c}}=850^{\circ} \mathrm{C}\right)$ in ageing experiments in a quartz reactor at $T_{\mathrm{R}}=800^{\circ} \mathrm{C}$

\begin{tabular}{lllllll}
\hline Li/MgO & \multicolumn{2}{l}{ Li (wt.-\%) } & & \multicolumn{2}{l}{$C_{2}$ selectivity $(\%)$} \\
\cline { 6 - 7 } \cline { 6 - 7 } & Fresh & Used & & $5 \mathrm{~h}$ & $40 \mathrm{~h}$ & $65 \mathrm{~h}$ \\
\hline $\mathrm{A} 1$ & 2.18 & 0.41 & & 80.6 & 73.8 & 72.7 \\
$\mathrm{~A} 2$ & 3.52 & 0.84 & & 81.5 & 81.4 & 81.0 \\
$\mathrm{~B}$ & 3.10 & 0.20 & & 83.1 & 82.4 & 83.2 \\
$\mathrm{C}$ & 5.40 & 1.73 & & 78.2 & 72.4 & - \\
D1 & 1.70 & 0.42 & & 80.8 & 81.6 & 80.5 \\
D2 & 3.20 & $-{ }^{a}$ & & 80.2 & 78.8 & 79.5 \\
\hline
\end{tabular}

\footnotetext{
${ }^{a}$ Not measured.
} 
trated at the surface of the powdered materials and that a more homogeneous distribution resulted upon fusing the samples.

It was possible to use the $\mathrm{Li} / \mathrm{MgO} \mathrm{A} 1$ catalyst for $90 \mathrm{~h}$ without any deactivation using a fused $\mathrm{Al}_{2} \mathrm{O}_{3}$ reactor, using the same reaction conditions as used for the results in Fig. 4 [9]. In this case, any deactivation of the catalyst occurring appears to be caused mainly by the formation of volatile $\mathrm{LiOH}$.

\section{Influence of hot spots on the ageing behaviour}

An important factor in the stability of $\mathrm{Li} / \mathrm{MgO}$ catalysts appears to be the occurrence of a hot reaction zone in the catalyst bed. Fig. 5 shows the results of an ageing experiment in a quartz reactor using the very active sample $\mathrm{Li}$ / $\mathrm{MgO} \mathrm{A} 1$. In this case, a quartz capillary was placed axially along the centre of the catalyst bed and a moveable thermocouple was placed in this capillary to allow a longitudinal axial temperature profile to be recorded.

The two curves of Fig. 5 show the temperature profiles measured for a fresh sample of $\mathrm{A} 1$ and for the same material after an ageing experiment of $15 \mathrm{~h}$. With the fresh sample, a hot zone was found at the beginning of the bed and this was found to travel in the direction of the flow and also to flatten out somewhat during the ageing experiment. It was found that the material from that part of the bed through which the hot zone had passed had lost significant amounts of lithium; for the experiment shown in Fig.5, which was terminated after $15 \mathrm{~h}$, the lithium content in the first part of the bed had fallen from the original 2.2 wt.- $\%$ to 0.4 wt.- $\%$, that in the middle of the bed had fallen to 0.8 wt. $\%$, whereas that at the end of the bed had not fallen much (to $1.2 \mathrm{wt} .-\%$ ).

\section{Influence of carbon dioxide and water on the stability of $\mathrm{Li} / \mathrm{MgO}$ catalysts}

We have shown in a previous paper [5], that carbon dioxide adsorbs competitively on the sites active for methane coupling. The addition of carbon

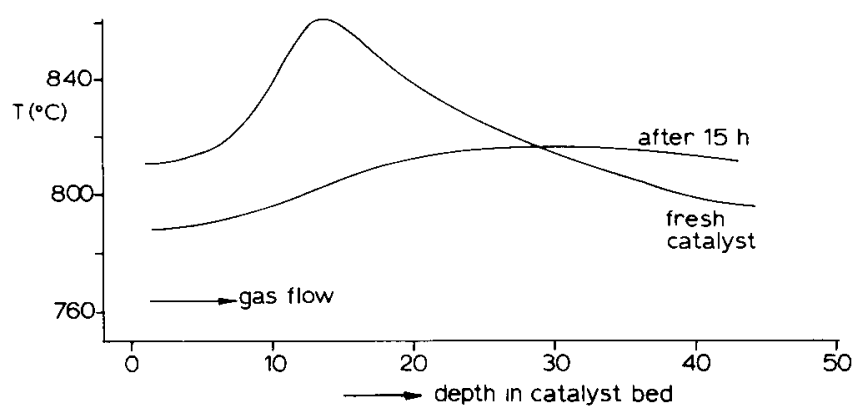

Fig. 5. Temperature in the catalyst bed as a function of the position in the bed. Catalyst: $\mathrm{Li} / \mathrm{MgO}$ A1. 
dioxide to the gas feed resulted in a poisoning of the catalyst. The deactivation of the catalyst could be retarded if low concentrations of carbon dioxide were added to the reaction mixture. In the case of $\mathrm{Li} / \mathrm{MgO} \mathrm{A1}$ and $\mathrm{Li} / \mathrm{MgO} \mathrm{B}$ $\left(T_{\mathrm{c}}=850^{\circ} \mathrm{C}\right)$, different concentrations of carbon dioxide were added to the gas feed to study the poisoning effect. The results are given in Table 3. As was shown above, $\mathrm{Li} / \mathrm{MgO} \mathrm{Al}$ was more active than is $\mathrm{Li} / \mathrm{MgO}$. The addition of low concentrations of carbon dioxide to the gas feed to the latter sample caused a severe poisoning of the catalyst; this poisoning effect of carbon dioxide was less in the case of $\mathrm{Li} / \mathrm{MgO} \mathrm{A1}$, low concentrations (1-2\%) causing almost no poisoning (Table 3 ). In the case of $\mathrm{Li} / \mathrm{MgO} \mathrm{A} 1$, there was a hot spot in the catalyst bed (see above).

It has been found, as was shown previously [5], that it is possible to stabilise a $\mathrm{Li} / \mathrm{MgO}$ catalyst against deactivation by the addition of carbon dioxide to the gas feed. More carbon dioxide was necessary to affect the stabilisation of $\mathrm{Li} / \mathrm{MgO}$ A1 than that of $\mathrm{Li} / \mathrm{MgO} \mathrm{B}$; it was found (see Fig. 6) that this catalyst could be stabilised against deactivation by adding $7.4 \% \mathrm{CO}_{2}$ to the gas feed (The rapid rise in $\mathrm{C}_{2}$ yield after $25 \mathrm{~h}$ is probably caused by a movement of the hot spot in the catalyst bed). When the carbon dioxide flow was stopped, after $95 \mathrm{~h}$, it was found (see Fig. 6) that the behaviour with respect to $\mathrm{C}_{2}$ production returned to that found for the fresh catalyst in the absence of carbon dioxide; however, deactivation now occured much more rapidly. Fig. 6 also shows for the same sample the effect of water addition to the gas feed; the addition is clearly very detrimental to the stability of the catalyst. Volatile $\mathrm{LiOH}$ was formed and this evaporated from the catalyst, travelling in the direction of the gas stream and resulting in the formation of a white deposit after the catalyst bed. The addition of carbon dioxide and water to the gas feed influenced only the activity; the $\mathrm{C}_{2}$ selectivities did not change (ca. $80 \%$ ), indicating that the

\section{TABLE 3}

The effect of the proportion of carbon dioxide in the feed on the $\mathrm{C}_{2}$ yields for $\mathrm{Li} / \mathrm{MgO} \mathrm{A} 1$ and $\mathrm{Li}$ / $\mathrm{MgO} \mathrm{B} ; T_{\mathrm{c}}=850^{\circ} \mathrm{C}, T_{\mathrm{R}}=800^{\circ} \mathrm{C}, \mathrm{C}_{2}$ selectivity $=80-84 \%$

\begin{tabular}{lll}
\hline$\% \mathrm{CO}_{2}$ & \multicolumn{2}{l}{$\mathrm{C}_{2}$ yield (\%) } \\
\cline { 2 - 3 } gasfeed & $\mathrm{Li} / \mathrm{MgO} \mathrm{A1}$ & $\mathrm{Li} / \mathrm{MgO} \mathrm{B}$ \\
\hline 0.00 & 13.7 & 12.2 \\
0.50 & $-^{a}$ & 6.6 \\
0.90 & - & 4.5 \\
2.00 & 13.2 & 3.8 \\
4.20 & 12.9 & - \\
7.40 & 11.9 & - \\
\hline
\end{tabular}

${ }^{a}$ not measured. 


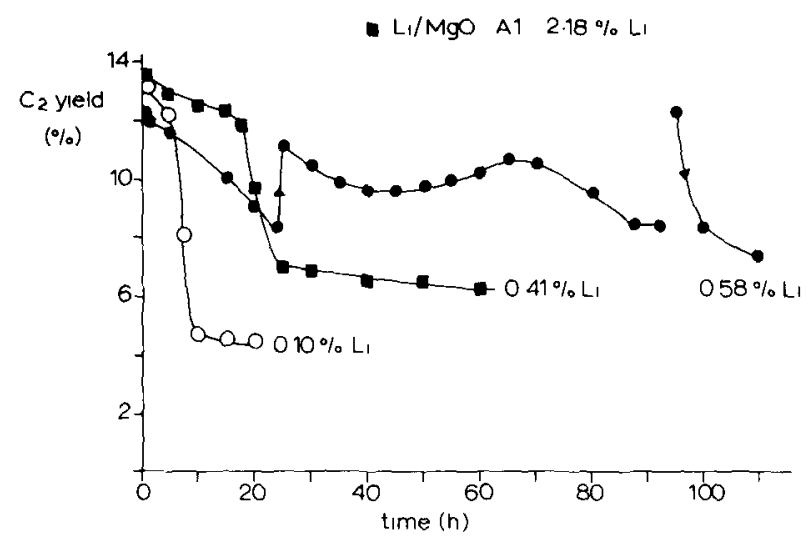

Fig. 6. The influence of carbon dioxide and water on the stability of $\mathrm{Li} / \mathrm{MgO} \mathrm{A} 1$ at $T_{\mathrm{R}}=800^{\circ} \mathrm{C}$. (O) $7.4 \%$ carbon dioxide, $(O) 3.0 \%$ water.

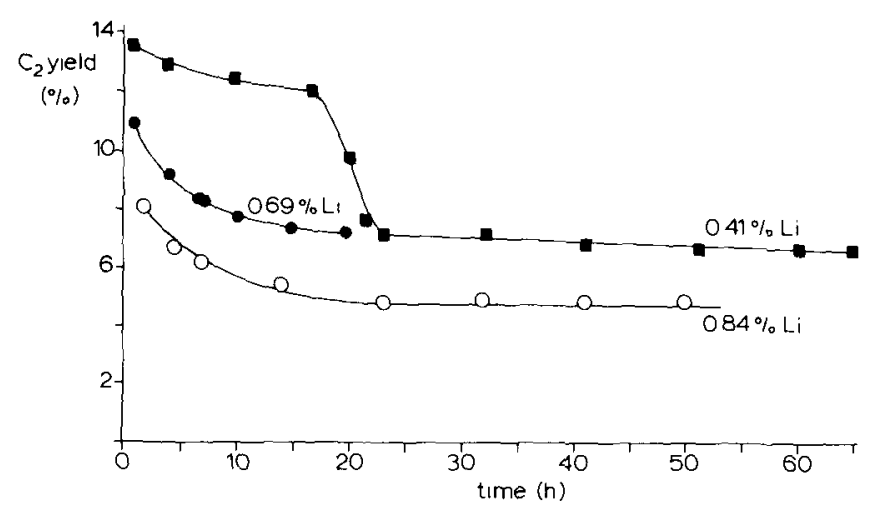

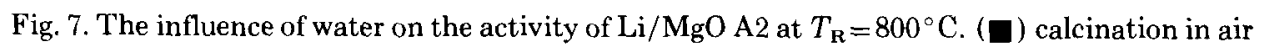
$\mathrm{A} 1,(\mathrm{O})$ calcination in carbon dioxide, $\mathrm{A} 2,(-)$ calcination in carbon dioxide, $\mathrm{A} 23 \%$ water.

nature of the active site had not altered appreciably and that only the number of active sites had changed.

As shown in Fig. 7, $\mathrm{Li} / \mathrm{MgO}$ A2 calcined in carbon dioxide at $850^{\circ} \mathrm{C}$ was a relatively inactive catalyst, giving initially a $\mathrm{C}_{2}$ yield of only $8.2 \%$; the results for $\mathrm{Li} / \mathrm{MgO} \mathrm{A1}$, prepared in the same way but calcined in air, are given for comparison purposes. The carbonate species are strongly bonded to the surface of the former material $\left(T_{\mathrm{d}}=700^{\circ} \mathrm{C}\right)$; XPS measurements showed a very low lithium content on its surface. Surprisingly, it was found that the initial behaviour of the sample $\mathrm{Li} / \mathrm{MgO} \mathrm{A} 2$ was improved by the addition of water to the gas feed (Fig. 7). Separate TPD measurements showed that the addition of water to the gas feed accelerates the decomposition of the lithium carbonate on the surface of the catalyst and this gives a possible explanation of the improved behaviour. 


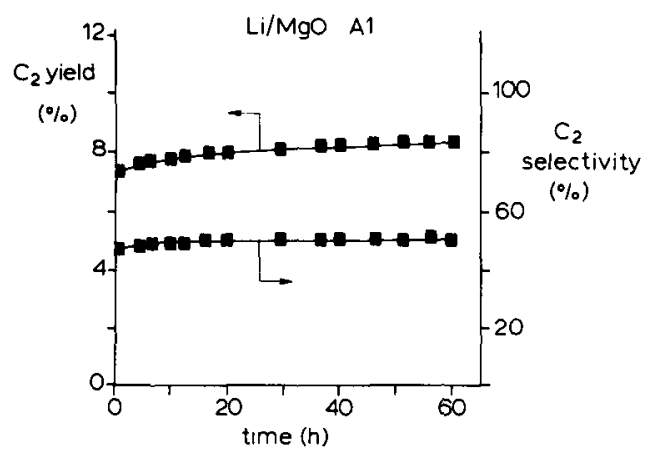

Fig. 8. The results of an ageing experiment in the recycle reactor. The yield of $\mathrm{C}_{2}$ products is shown as a function of time-on-stream at $800^{\circ} \mathrm{C}$ for $\mathrm{Li} / \mathrm{MgO} \mathrm{A} 1$.

Fig. 8 shows the results of an ageing experiment with $\mathrm{Li} / \mathrm{MgO} \mathrm{A} 1$ which was carried out in the recycle system at $800^{\circ} \mathrm{C}$; the $\mathrm{C}_{2}$ yield is shown as a function of the duration of the experiment. The selectivity to $\mathrm{C}_{2}$ products remained at about $50 \%$ throughout the experiment; this value is considerably lower than the values obtained using a single pass reactor, this probably being due to the back-mixing of the relatively unstable $\mathrm{C}_{2}$ products in the recycle system [10]. Comparison of the experiments given in Fig. 8 (using the recycle reactor) and Figs. 4 and 6 (using the plug flow reactor) shows that the stability of the $\mathrm{Li}$ / $\mathrm{MgO}$ catalyst is much better in the recycle reactor. This is probably caused by two factors: (i) The $\mathrm{CO}_{2} / \mathrm{H}_{2} \mathrm{O}$ ratio in the reactor is high, due to the recycling of carbon dioxide and the simultaneous removal of water in the recycle loop. (ii) Hot spots are absent in this gradientless reactor. Elemental analysis of the used catalyst showed that it still contained $1.8 \mathrm{wt}$. $\% \mathrm{Li}$, confirming that the lithium species are more stable under these conditions.

\section{Influence of periodical reversal of the direction of flow of the gas stream}

Using the high gas velocity conditions described in the Experimental section, a methane/oxygen ratio of $5\left(0.50\right.$ bar $\mathrm{CH}_{4}$ and 0.10 bar $\left.\mathrm{O}_{2}\right)$ and an active $\mathrm{Li} / \mathrm{MgO}$ catalyst, a hot spot is always found in the catalyst bed and a reaction front moves through the bed in the direction of the gas stream (see above). The results of two ageing experiments using a bed of $1500 \mathrm{mg}$ of $\mathrm{Li} / \mathrm{MgO} \mathrm{B}$ $\left(T_{\mathrm{c}}=850^{\circ} \mathrm{C}\right)$ at $T_{\mathrm{R}}=780^{\circ} \mathrm{C}$ with a methane/oxygen ratio of 5 are given in Fig. 9 ; in one experiment, the flow was kept constant, in the other it was reversed periodically. For the first experiment, the initial $\mathrm{C}_{2}$ yield was $19.0 \%$ and the $\mathrm{C}_{2}$ selectivity was $67 \%$. After reaction for $13.5 \mathrm{~h}$ the reaction front reached the end of the catalyst bed, and there was then a very rapid decrease in the $\mathrm{C}_{2}$ production; after the experiment, the catalyst contained $0.18 \mathrm{wt} .-\% \mathrm{Li}$ and 0.21 wt.- $\% \mathrm{CO}_{2}$. When the reaction front reaches the end of the catalyst bed, a 


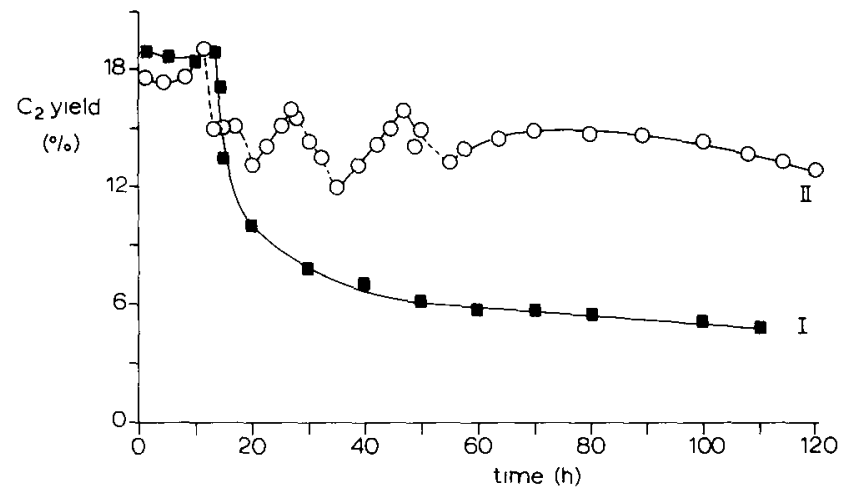

Fig. 9. The yield of $\mathrm{C}_{2}$ products as a function of time of reaction at $780^{\circ} \mathrm{C}, P_{\mathrm{CH}_{4}} / P_{\mathrm{O}_{2}}=5$ ) for $\mathrm{Li} /$ $\mathrm{MgO} \mathrm{B}$ in an up-flow experiment as well as for an experiment in which the reactant flow was periodically reversed. I ( $\mathbf{(})$ up flow; II $(\mathrm{O}-\mathrm{O})$ up flow, $(\mathrm{O}--\mathrm{O})$ down flow.

substantial amount of lithium will evaporate from the catalyst (as $\mathrm{LiOH}$ ) and will travel in the direction of the gas stream, resulting in the white deposit observed on the exit tube of the reactor.

With the intention of keeping the lithium in the catalyst bed and of achieving a stable behaviour with the catalyst, the second experiment was carried out in which the direction of flow of the gas stream was reversed periodically; the direction of flow was changed for the first time after $8 \mathrm{~h}$ (see Fig. 9). It was found that the subsequent stability of the catalyst was much improved; the yield remained much higher, even after the reversal steps were stopped, than with normal experiments. After the experiment, the catalyst contained 0.27 wt. $\% \mathrm{Li}$, a higher value than that found in the case of the up-flow experiment. However the lithium content of the catalyst was still remarkably low compared with the fresh material. This effect shows that only small amounts of lithium are needed to create the active sites on the surface of the $\mathrm{Li} / \mathrm{MgO}$ catalyst and this lithium must be present in the correct position. By periodical reversal of the direction of flow of the gas stream, it is thus possible to create an ideal distribution of the lithium on the surface of the catalyst.

Reaction model for the Li/MgO catalyst system

A schematic representation of the reactions occurring on the catalyst surface is shown in Fig. 10. A good $\mathrm{Li} / \mathrm{MgO}$ catalyst consists of $\mathrm{Li}_{2} \mathrm{CO}_{3}$ and $\mathrm{MgO}$. Active sites are created on the surface of the catalyst by the gradual loss of carbon dioxide from surface lithium carbonate species in the presence of oxygen; the presence of lithium carbonate on the surface of the catalyst is therefore crucial for its activity. Gas pretreament results (Fig. 1) show that the decomposition of the lithium carbonate species in the absence of oxygen is detrimen- 


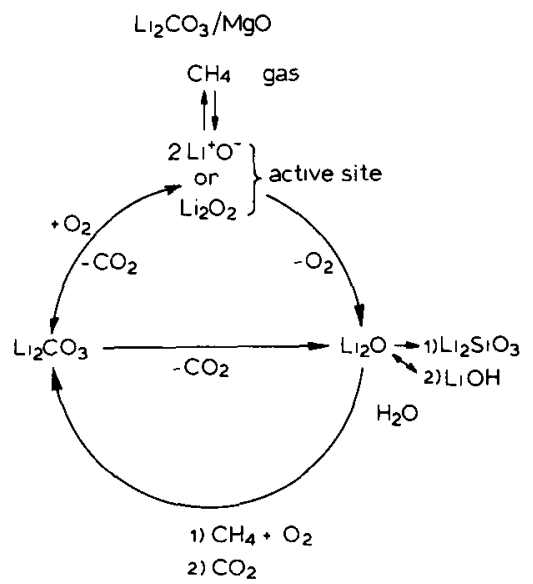

Fig. 10. Scheme showing the possible interrelation between the surface species on $\mathrm{Li} / \mathrm{MgO}$ catalyst.

tal to the activity of the catalyst. The active sites created in the presence of oxygen are relatively unstable; the active oxygen species may be $\mathrm{O}^{-}, \mathrm{O}_{2}^{-}$or $\mathrm{O}_{2}^{2-}$. Reaction of methane with the active site gives rise to the formation of a methyl radical and a reduced surface site. According to the mechanism proposed by Ito et al. [2], this reduced site is a $\mathrm{LiOH}$ species; in the catalytic cycle of their model, two of these species react to give $\mathrm{Li}_{2} \mathrm{O}$ and water, followed by re-oxidation of $\mathrm{Li}_{2} \mathrm{O}$ with gas-phase oxygen to form two $\mathrm{Li}^{+} \mathrm{O}^{-}$sites. Thus, if the model proposed by Ito et al. holds, $\mathrm{Li}_{2} \mathrm{O}$ may be formed as an intermediate of the oxidative coupling reaction; it may also be formed as an intermediate by direct decomposition of $\mathrm{Li}_{2} \mathrm{CO}_{3}$. The $\mathrm{Li}_{2} \mathrm{O}$ is likely to react further, it being less stable than $\mathrm{LiOH}, \mathrm{Li}_{2} \mathrm{CO}_{3}$ or $\mathrm{Li}_{2} \mathrm{SiO}_{3}$. In the presence of a high $\mathrm{H}_{2} \mathrm{O} / \mathrm{CO}_{2}$ ratio, volatile $\mathrm{LiOH}$ entities will be formed; this will give rise to the loss of active species, as discussed above. In the presence of carbon dioxide, the carbonate species forms instead of the volatile hydroxide, this giving an improvement of the catalyst stability and hindering the formation of volatile species but poisoning the reaction. In the case of strongly bonded $\mathrm{Li}_{2} \mathrm{CO}_{3}$ on the surface of a $\mathrm{Li} / \mathrm{MgO}$ catalyst, the decomposition of the carbonate, and thus the activity, can be enhanced by addition of water to the reaction mixture. It would appear that the intermediate surface $\mathrm{OH}$ species postulated in the model of Ito et al. [2] to be formed by the reaction of methane with surface oxygen species do not give rise directly to the loss of lithium species from the catalyst; we conclude this from the fact that deactivation of the catalyst is diminished at low $\mathrm{H}_{2} \mathrm{O} / \mathrm{CO}_{2}$ ratios. Another important route for the loss of lithium from the catalyst is the formation of lithium meta silicate.

\section{CONCLUSIONS}

1. The behaviour of $\mathrm{Li} / \mathrm{MgO}$ catalysts depends markedly on the method used for their preparation. Passing carbon dioxide through the evaporating solution 
during impregnation results in a higher amount of lithium present as carbonate, and in segregation of lithium on the surface of the catalyst. The catalysts obtained are very active. The optimum lithium content of the fresh catalyst is ca. $2-4$ wt. $\%$.

2. Active sites are created on the surface of a $\mathrm{Li} / \mathrm{MgO}$ catalyst by the gradual loss of carbon dioxide from surface lithium carbonate species in the presence of oxygen. Decomposition of the lithium carbonate species in the absence of oxygen is detrimental to the activity of the catalyst.

3 . The active sites created are not stable. The deactivation of the catalysts is caused by the loss of lithium as $\mathrm{Li}_{2} \mathrm{SiO}_{3}$ or as the volatile species, $\mathrm{LiOH}$. In general, the addition of water to the gas feed is detrimental to the stability of the catalyst. In the case of $\mathrm{Li}_{2} \mathrm{CO}_{3}$ strongly bonded on the surface of $\mathrm{Li} / \mathrm{MgO}$ catalyst, the decomposition of the carbonate, and thus the activity, can be enhanced by the addition of water to the gas feed.

4. In regions containing hot spots greatest loss of lithium carbonate is found.

5. The presence of carbon dioxide in the gas feed has two effects, namely to poison reversibly the active sites for the oxidative coupling reaction but also to stabilise them against deactivation.

6. To reach a stable behaviour of the catalyst, an equilibrium between $\mathrm{Li}_{2} \mathrm{CO}_{3}$ and $\mathrm{LiOH}$ is necessary. It is possible to improve the stability of the catalyst by periodic reversal of the direction of flow of the gas stream. After this experiment, the catalyst contains more lithium than in a normal up-flow experiment and an ideal distribution of lithium on the surface of the catalyst is reached. The stability of the catalyst can also be improved by using an $\mathrm{Al}_{2} \mathrm{O}_{3}$ reactor instead of a quartz reactor.

\section{ACKNOWLEDGEMENTS}

S.J.K. thanks the Dutch Foundation for Scientific Research (NWO) for financial support. We also thank G.J.M. Weierink for technical assistance and the Non-Nuclear Energy programme of the European Community for partial support of the work (Contract No. EN3C-039-NL (GDF)). Finally, we should also like to thank the Salt and Basic Chemicals Division of Akzo for a financial contribution.

\section{REFERENCES}

1 T. Ito and J.H. Lunsford, Nature (London), 314 (1985) 721.

2 T. Ito, J.-X. Wang, C.-H. Lin and J.H. Lunsford, J. Am. Chem. Soc., 107 (1985) 5062.

3 G.A. Martin and C. Mirodatos, J. Chem. Soc., Chem. Commun., (1987) 1393.

4 K. Otsuka, K. Jinno and A. Morikawa, J. Catal., 100 (1986) 353.

5 S.J. Korf, J.A. Roos, N.A. de Bruijn, J.G. van Ommen and J.R.H. Ross, Catal. Today, 2 (1988) 535. 
6 J.A. Roos, A.G. Bakker, H. Bosch, J.G. van Ommen and J.R.H. Ross, Catal. Today, 1 (1987) 133.

7 J.A. Roos, S.J. Korf, R.H.J. Veehof, J.G. van Ommen and J.R.H. Ross, Catal. Today, 4 (1989) 441.

8 K.R. Westerterp, W.P.M. van Swaaij, A.A.C.M. Beenackers, Chemical Reactor Design and Operation, Wiley, Chichester, 1984.

9 S.J. Korf, J.A. Roos, L.J. Veltman, J.G. van Ommen and J.R.H. Ross, Appl. Catal., 56 (1989) 119.

10 J.A. Roos, S.J. Korf, A.G. Bakker, N.A. de Bruijn, J.G. van Ommen and J.R.H. Ross, in D.M. Bibby, C.D. Chang, R.F. Howe and S. Yurchak (Editors), Methane Conversion, Studies in Surface Science and Catalysis, Vol. 36, Elsevier, Amsterdam, 1988, p. 535. 